\title{
ASSOCIATIONS OF EDUCATION, KNOWLEDGE, AND ATTITUDE WITH ANTENATAL CARE VISIT IN MEDAN, NORTH SUMATERA
}

\author{
Polma Ria Metawati Panjaitan, Heru Santosa, Surya Utama \\ Masters Program in Public Health, Universitas Sumatera Utara
}

\begin{abstract}
Background: It has been estimated that 25 percent of maternal deaths occur during pregnancy. Therefore, good care during pregnancy is important for the health of the mother and the development of the unborn baby.This study aimed to determine the associations of education, knowledge, and attitude with antenatal care (ANC) visit in Medan, North Sumatera.

Subjects and Method: This was a case control study conducted at Ridos General Hospital, Medan, North Sumatera. A sample of 89 pregnant women was selected for this study. The dependent variable was completeness of ANC. The independent variables were education, knowledge, and attitude. The data were collected by questionnaire. The data were analyzed by a multiple linear regression.

Results: Knowledge about pregnancy and birth delivery $(b=048 ; p=0.045)$ was associated with completeness of ANC visit, after controlling for the effects for other variables.

Conclusion: Knowledge about pregnancy and birth delivery is associated with completeness of ANC visit.
\end{abstract}

Keywords: antenatal care, education, knowledge, attitude, pregnant women.

\section{Correspondence:}

Polma Ria Metawati Panjaitan. Masters Program in Public Health, Universitas Sumatera Utara, Jalan Universitas No.21, Kampus USU, Medan 20155, North Sumatera. Email: happypolma@yahoo.com.Mobile: 081370801033. 